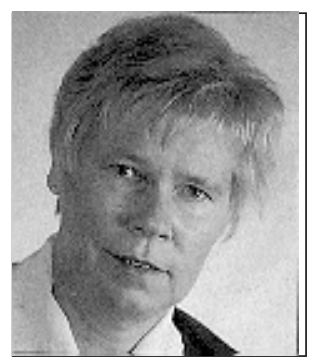

Anneli Luukas

\title{
Kokemuksia vieraskielisen yrityspelin käytöstä
}

\section{Varsinaista pääainetta voi opiskella myös vieraskielisten simulaatio- pelien avulla. Näin saadaan kaksi kärpästä yhdellä iskulla: opitaan sisältöjä ja vierasta kieltä. Helsingin Liiketalouden Ammattikorkeakoulussa on usean vuoden kokemus Strategy! -yrityspelistä, jossa pyritään kilpaillen tekemään oikeaa liiketaloudellista "tulosta".}

Globalisaatio ja tietotekninen kehitys yhdessä ovat tuoneet uusia käänteentekeviä ratkaisumahdollisuuksia oppimiseen ja opetukseen. Oppimistapahtuma voidaan toteuttaa pääasiassa avoimessa oppimisympäristössä, kunhan se on tavoitteellinen, mielekäs ja toimiva. Tietotekniikkaa hyödyntäen voidaan rakentaa uudenlaisia opetuskokonaisuuksia, joissa eri aineet yhdistyvät. Näin päästään lähemmäs reaalimaailman ilmiöitä ja pystytään esittämään monimutkaista todellisuutta mahdollisimman monipuolisesti ja konkreettisesti (VanSickle 1978 teoksessa Ruohomäki ja Vartiainen 1992:13). Kehitys on muuttanut sekä opiskelijoiden että opettajien suhtautumista oppimiseen ja opettamiseen. Molemmista on tullut oppijoita ja uteliaita uusien mahdollisuuksien hyväksikäyttäjiä, oppimisen yhteistyökumppaneita.

Myös vieras kieli voidaan kytkeä luontevasti sisältöaineiden opetukseen uuden tekniikan avulla. Sisällön opetus vieraalla kielellä (TCFL), varsinkin englanniksi (TCE), on lisääntynyt voimakkaasti (Marsh et al. 1996). Kielenopettajan asiantuntemuksen hyödyntäminen vieras- kielisessä sisältöopetuksessa on koettu tärkeäksi (Anttila et al. 1995). Vieraiden kielten sitominen sisältöopetukseen on myös Euroopan neuvoston koulutuspolitiikan mukaista: neuvosto kannustaa jäsenmaita monikieliseen opetukseen, josta käytetään mm. nimitystä 'plurilingual approach' tai Content and Language Integrated Learning (CLIL) (White Paper 1995; Marsh 1996, Tempus 8, 6-7).

Yksi tapa nivoa sisältö ja vieras kieli integroiduksi kokonaisuudeksi on käyttää opiskelijan pääaineisiin liittyvää vieraskielistä simulaatiota lähtökohtana ja rakentaa sen ympärille kansainvälisiä vuorovaikutustilanteita. Vuodesta 1992 olen osallistunut englannin opettajana ammattikorkeakoulussani opetuksen ja oppimisen kehittämishankkeeseen. Sen tavoitteena on ollut integroida usean aineen oppiminen todellisuutta muistuttavaksi oppimiseksi simulaation avulla tietotekniikkaa hyödyntäen. Oppimisympäristönä on ollut amerikkalainen, kaupallisesti tarjolla oleva tietokoneavusteinen yrityspeli, Strategy! Business Unit Simulation (Priesmeyer, 1992). Peli edellyttää yritystalouden, 


\section{UUTTAKOULUTUKSESSA}

laskennan, markkinoinnin ja tietotekniikan perustietoja ja -taitoja sekä hyvää englannin taitoa, sillä peli ja manuaali ovat englanninkielisiä.

Yrityspelejä ja simulaatioita on käytetty yrityskoulutuksessa 1950-luvulta lähtien ja niiden määrän arvioidaan nykyisin olevan pitkälti yli 200 (Kauppi 1995:58). Suomessa lienee käytössä kymmenkunta peliä. Kaupin (1995:59) mukaan yrityspelien ja -simulaatioiden kehittäminen on läheisessä kytköksessä työelämän kehittymiseen, kuten uuteen teknologiaan, liike-elämän kansainvälistymiseen ja muutoksiin tuotantojärjestelmissä. Omassa projektissamme on pyritty ottamaan huomioon nimenomaan nämä työelämän vaatimukset, kun olemassaolevan yrityspelin ympärille on lähdetty kehittämään laajempaa oppimisympäristöä. Ulkomaisten kumppaneiden sitominen mukaan peliin on ollut yksi tapa hyödyntää uusia tietotekniikan mahdollisuuksia, kuten sähköpostia ja Internetiä, ja harjoitella kansainvälistä viestintää aidoissa kommunikaatiotilanteissa. Tältä osin käyttämämme yrityspelin eri toteutustavat edustavat innovatiivisia oppimiskäytäntöjä.

Alun perin saimme kutsun Strategy!-yrityspeliin vuonna 1992 Havaijin yliopiston kasvatustieteen professorilta Morton Cotlarilta. Havaijilaiset liiketaloustieteen opiskelijat olivat pelanneet peliä telemaattisesti yhteistyössä mm. japanilaisten yritysjohtajien ja muunmaalaisten opiskelijoiden kanssa (Bailey ja Cotlar 1994184193) ja mukaan toivottiin myös suomalaisia pelaajia. Pelaaminen edellytti sähköpostiyhteyttä, joka vuonna 1992 oli uusi väline oppilaitoksessamme. Pelin toteutusta lähti ideoimaan vapaaehtoinen tiimi, johon kuului Antti Kauppi tutkijana ja yhteyshenkilönä sekä eri oppiaineita edustavia opettajia (yritystalous, markkinointi ja englanti). Koska peli edellytti uusien tietoteknisten valmiuksien luomista oppilaitostasolla, myös oppilaitoksen atk-asiantuntijaa tarvittiin. Itse olen toiminut hankkeen vetäjänä ja koordinaattorina. Tutkin myös vieraan kielen oppimisstrategioita kyseisessä peliympäristössä (Luukas 1997b).
Vuosina 1993-94 Suomen Liikemiesten Kauppaopiston (aiempi nimi) opettajankoulutusosaston opetusharjoittelijoiden kaksi ns. hankeryhmää, joissa oli edustettuina liiketalouden, viestinnän, toimistoteknisten aineiden ja englannin kielen opettajia, otti tutkimuksensa kohteeksi pelin kehittämisen opetukselliseksi ratkaisuksi. Se pyrki selvittämään, minkälaisia mahdollisuuksia uutta teknologiaa hyödyntävä monen aineen yhteisprojekti tarjoaisi oppimiselle ja opettamiselle. Tuloksena syntyivät opetuskokeilut Aloha! ja Strategy! ja raportit niistä (Aittooja et al. 1993, Halonen et al. 1994). Hankkeet olivat myös osa Utopia-projektia (Kauppi 1995). Lisäksi tarkastelin itse opetuskokeiluja vieraan kielen oppimisen näkökulmasta osana Euroopan neuvoston ammatillisen kielenopetuksen projekteja (Luukas 1995, 1996). Yhtenä tavoitteena opetuskokeiluissa oli kehittää ammattikorkeakoulun opiskelijoille sopiva, tietotekniikkaa hyödyntävä sisällöllisesti integroitu kurssi, jota voitaisiin tarjota toisen ja kolmannen vuoden opiskelijoille valinnaisena kurssina. Tämä tavoite toteutui vuonna 1995 ja kurssi on edelleen opetusohjelmassa (Helia, 302-303).

Strategy!-kurssiin on tähän mennessä osallistunut noin 100 ammattikorkeakoulumme opiskelijaa (mukaanlukien vaihto-opiskelijat), viisijäseninen opettajaryhmä, joka pelasi tasavertaisena opiskelijaryhmien kanssa keväällä 1997, sekä ulkomaisia pelikumppaneita ammattikorkeakouluista ja yrityksistä. Edustettuina ovat olleet itävaltalainen Johannes Kepler Universität Linzistä, Hanzehogeschool Groningen ja Hanzehogeschool Rotterdam Hollannista, Fachhochschule Reutlingen Saksasta, eteläkorealaisen tietokonealan yrityksen johtoryhmä sekä joitakin yksittäisiä pelaajia, jotka ovat saaneet tiedon pelistä oppilaitoksen kotisivulta (http://www@helia.fi/ eerma/strategy.html). Ulkomaiset pelaajat ovat toimineet yhteistyössä suomalaisten pelaajien kanssa, eivät erillisinä omina joukkueinaan.

\section{Strategy!-pelin rakenne, sisältö ja tavoitteet}

Peliä pelataan 2-5 hengen tiimeissä. Yhteen 
peliin mahtuu 6-8 tiimiä. Tiimit tekevät Porterin (1985) kilpailustrategioihin perustuen yritysten strategiseen suunnitteluun, markkinointiin ja laskentaan liittyviä päätöksiä, jotka viedään päätöslevykkeelle ja joiden vaikutus yritysten liiketulokseen prosessoidaan peliohjelmalevykkeellä kierros kierrokselta. Tuloksista näkyvät joukkueitten sijoitus ja panostusten määrä markkinointiin, tuotekehittelyyn, henkilöstön kehittämiseen jne. toimialoittain. Saadut tunnusluvut toimivat pohjana uuden pelikierroksen päätöksenteolle. Kukin kierros edustaa yhtä vuosineljännestä yritysten toiminnassa. Näin edetään sovitut määrät pelikierroksia (maksimi 12 kierrosta) ja lopuksi nähdään tiimien lopullinen sijoitus.

Kokeiltuamme peliä eri pituisena olemme päätyneet nykyiseen kahdeksaan kierrokseen eli kahteen liiketoimintavuoteen. Sinä aikana opiskelijat saavat tuntuman yritysten päätöksenteon problematiikkaan ja ehtivät nähdä valitsemansa liiketoimintastrategian vaikutukset sekä oppia pelin logiikan.

\section{Strategy! opetuskokeilut}

Ensimmäiseen varsinaiseen Strategy!-kokeiluun vuonna 1993 osallistui kaksi ammattikorkeakoulumme opiskelijaa, jotka kirjoittivat kokemuksistaan raportin (Saikku ja Rinne 1993). He pelasivat osana havaijilaista joukkuetta ja toimivat Euroopan toimintojen johtajina. Pelin 12 kierroksen kuluessa he vaihtoivat yhteensä 200 sähköpostiviestiä keskustellessaan havaijilaisen 'toimitusjohtajansa' kanssa tehtävistä päätöksistä. Suomalaiset opiskelijat pelasivat peliä täysin itsenäisesti ilman minkäänlaista muuta ulkopuolista ohjausta kuin toimitusjohtajan neuvot. Raportissaan he pitivät peliä mielenkiintoisena ja opettavaisena, mutta arvostelivat sitä myös joiltakin osin liian suljettuna järjestelmänä. Esimerkiksi kysyntä ei heidän mielestään vaikuttanut tarjontaan samalla tavoin kuin reaalielämässä. Peli oli opiskelijoiden mielestä helppo, varsinkin englannin osalta. Viestien kielellinen taso oli korkea ja sisälsi paljon ammattikieltä. Tämä ehkä selittyi toisen pelaajan lä- hes syntyperäisen puhujan kaltaisella englanninkielen taidolla. Myös muiden kielten (saksa, espanja) vaatimuksista pelaajat selvisivät hyvin.

Vuonna 1993-94 usean eri oppiaineen opetusharjoittelijoista muodostunut kuuden hengen hankeryhmä ideoi pelille didaktisen mallin, jota he kokeilivat keväällä 1994 vapaaehtoisena kurssina. Siihen osallistui 10 ammattikorkeakoulun opiskelijaa kolmena tiiminä. Mallissa eri oppiaineet integroituivat pelissä kokonaisuudeksi kuitenkin niin, että kullakin aineella oli myös omat oppimistavoitteensa. Toteutukseen kuului orientointipäivä, jonka aikana eri osaalueiden asiantuntijaopettajat (opetusharjoittelijat) selvittivät pelin tavoitteet liiketoiminnan, tietotekniikan ja vieraan kielen näkökulmasta. Tämän jälkeen opiskelijatiimit pelasivat kuusi pelikierrosta, joiden aikana heidät velvoitettiin pitämään englanniksi lokikirjaa päätöksistä ja oppimiskokemuksistaan. Lopuksi harjoittelijat järjestivät evaluaatiotilaisuuden, jossa pelaajat esittelivät omat strategiansa, ja parhaat pelaajat saivat leikkimielisen palkinnon. Hankeryhmä myös kehitti pelaajille englanninkielisen diplomin.

Sekä hankeryhmän opetusharjoittelijoiden että pelaajien kokemukset olivat rohkaisevia, vaikkakin teknisiä ja muita ongelmia oli runsaasti. Strategy! koettiin motivoivaksi ja erilaiseksi tavaksi syventää liiketoiminnan tietoutta. Yksi demotivoiva tekijä oli se, että havaijilaisia opiskelijoita ei ollut mukana tällä kertaa, kuten alunperin oli suunniteltu, vaan suomalaiset opiskelijat pelasivat tiimeinä vain toisiaan vastaan. Näin vieraan kielen osuus supistui manuaalin ymmärtämiseen ja lokikirjan pitämiseen englanniksi ja varsinainen kommunikaatio vieraalla kielellä jäi pois. Opiskelijat selvisivät manuaalin ymmärtämisestä hyvin. Vieraskielisten yhteyksien puuttuessa sähköpostin käyttö jäi myös pois, mikä koettiin pettymyksenä. Hankeryhmän raportissa (Halonen et al. 1994) todettiin, että Strategy! sopisi hyvin integroiduksi ammattikorkeakoulun kurssiksi, mutta kurssin toteuttaminen edellyttäisi useamman opettajan yhteisvastuuta kurssin toteuttamiseksi ja uudenlaista, konsultoivaa opettajuutta. 


\section{UUTTAKOULUTUKSESSA}

\section{Strategy!-kurssi ammattikorkeakoulussa}

Strategy!-kurssi otettiin opetusohjelmaan syksyllä 1995. Nykyinen toteutusmalli perustuu paljolti yllämainittuun opetusharjoittelijoiden kehittämään malliin, mutta sitä on pyritty rikastamaan sitä mukaa, kun tietotekniset ja muut valmiudet ovat kehittyneet. Esimerkiksi ulkomaiset pelaajat voivat nykyisin ladata pelikierrosten alkutiedot suoraan www:stä tiiminsä salasanaa vastaan, kun ne aikaisemmin jouduttiin lähetettämään tiedostoina.

Kurssin nykyinen laajuus on kaksi opintoviikkoa $(80 \mathrm{~h})$, josta 11 tuntia on kontaktiopetusta ja loput tiimien itsenäistä työskentelyä, kuten manuaaliin tutustumista ja pelipäätösten tekemistä. Yleensä yhden kierroksen päätöksentekoon kuluu tiimiltä aikaa 1-3 tuntia. Koska peli on tietokoneohjattu, kontaktituntien määrä on pieni. Kontaktiopetuksen ulkopuolella opiskelijatiimit voivat toimia haluamanaan aikana tai haluamassaan paikassa. Ainoa ehdoton ajallinen vaatimus pelissä on, että päätökset pitää jättää levykkeellä tietotekniikan opettajalle sovittuun määräaikaan mennessä tulosten ajamiseksi. Levykkeen myöhästyminen vaikuttaa alentavasti tiimin arvosanaan, koska se viivästyttää kaikkien tiimien tulosten ajoa. Pelaajien on myös otettava huomioon aikaerot niin, että ulkomaisten partnereiden päätökset ehtivät määräaikaan mennessä.

Oppimisprosessin dokumentoimiseksi tiimit on velvoitettu pitämään lokikirjaa, joka luovutetaan pelin lopussa opettajatiimille arviointia varten. Siihen he kirjaavat seuraavia asioita pelikierroksittain: Round (No.), problems, action taken / decision - why?, effect / result.

Koko kurssi toteutetaan englanniksi ja sen toteutusvaiheet ovat 1) ennakkoinformaatio, 2) alkuorientaatio (neljä tuntia), 3) tutustuminen tiimeittäin peliin käsikirjan avulla (kaksi kalenteriviikkoa), 4) jatko-orientaatio (neljä tuntia), 5) pelikierrokset (2-5, kierros viikossa), 6) välikokous, 7) pelikierrokset 6-9 (kierros viikossa) sekä 8) loppuevaluaatio (kaksi tuntia).

\section{Kurssin arviointi}

Arvioinnissa kiinnitetään huomiota seuraaviin asioihin laadullisesti: business-strategia (johdonmukaisuus, käyttökelpoisuus, strategian noudattaminen), sijoitus eli ranking pelissä, väliraportin sisältö ja laatu, lokikirja ja muu dokumentointi, peliaikataulun noudattaminen ja yhteydenpito ulkomaisiin partnereihin (viestien määrä ja laatu).

Näiden yhteissummana saadaan tiimien lopulliset arvosanat. Kukin tiimin jäsen saa saman arvosanan. Pelin voittanut tiimi saa yleensä arvosanan kiitettävä, jos muut osa-alueet on hoidettu hyvin. Oppimistulosten näkökulmasta pelissä heikommin menestynyt tiimi on saattanut oppia yhtä paljon kuin parhaiten menestyneet tiimit. Yksi oppimisvaikutus näkyy siinä, kuinka hyvin opiskelijat pystyvät arvioimaan peliä verattuna todelliseen liike-elämään. Mikäli opiskelijat huomaavat puutteita pelin sisäisessä rakenteessa, arvioivat peliä tältä kannalta ja tekevät ehdotuksia pelin monipuolistamiseksi, se osoittaa, että he pystyvät analysoimaan toimintojensa vaikutuksia ja siirtämään oppimaansa myös todelliseen elämään. Tämä on merkki siirtovaikutuksesta ja ja laadukkaasta oppimisprosessista.

Arvosanan lisäksi osallistujat saavat englanninkielisen diplomin, jossa on kaikkien tiimin jäsenten nimet (myös ulkomaalaisten pelaajien) sekä kurssin sisältökuvaus. Näin pelaajat voivat esitellä osaamistaan myöhemmin työnhakutilanteessa.

Saadun palautteen perusteella opiskelijoiden kokemukset ovat olleet lähes poikkeuksetta myönteisiä, koska kurssi on erilainen kuin muut niin toteutustavaltaan kuin sisällöltäänkin. Negatiivisimmat kokemukset ovat olleet hävinneitten tiimien jäsenillä. Tämä osoittaa pelimenestyksen motivaatioarvoa oppimisen kannalta. Pelissä yhdistyvät yritystoiminnan teoria ja käytäntö ja strategisten päätösten vaikutukset näkyvät pelikierrosten tuloksissa, joskaan eivät aina heti seuraavalla kierroksella. Näin opiskelijat oppivat analysoimaan tekemiään strategi- 
sia ratkaisuja ja niiden vaikutuksia kriittisesti ja miettimään tarvittavia korjaustoimenpiteitä. Peli oppimismuotona motivoi oppimaan itsenäisesti, koska siinä on kilpailun mukanaan tuomaa jännitystä. Oppijoiden mielestä peli voisi olla monimutkaisempi, mikä lisäisi motivaatiota.

Yksi tärkeä havainto pelin avulla tapahtuvasta oppimisesta on ollut, että mikäli yhteistyö tiimin jäsenten kesken ei ole toiminut syystä tai toisesta, myös loppusijoitus pelissä on ollut heikko. Sosiaaliset taidot ja niiden harjoitteleminen ovat siis oleellinen osa pelin avulla tapahtuvaa oppimista. Samoin, jos tiimin pelin alussa laatima business-strategia on ollut heikko, pelimenestys on jäänyt vaatimattomaksi. Peli siis näyttäisi heijastavan reaalielämän lainalaisuuksia.

\section{Oppilastutoreista hyvä kokemus}

Uusi ulottuvuus pelin ohjauksessa on oppilastutorit. Ajatus tutoreista tuli vuonna 1995 kahdelta peliä pelanneelta opiskelijalta. He halusivat hyödyntää omaa kokemustaan opastamalla uusia pelaajia. Lisäksi heitä jäi kiehtomaan pelin jännitys ja se, että he eivät vielä hallinneet peliä. Kyse oli siis eräänlaisesta laatuoppimisesta: oppijat halusivat tulla 'mestareiksi' (ks. Lave ja Wenger 1991). Tutorit halusivat myös saada laajemman kuvan pelistä eli nähdä, miten eri tavoin seuraavat tiimit toimisivat ja minkälaisia strategioita ne valitsisivat. Omaa kokemustaan tutorit hyödynsivät pelin ohjauksessa tuomalla uusia ideoita pelin toteuttamiseen.

Tutorit saavat työstä kaksi opintoviikkoa. Tutoreilla on oma toimenkuva, jonka kehittämiseen he itse osallistuvat. Siihen sisältyy mm., että tutorit valmistelevat pelin toteutuksen yhdessä opettajatiimin kanssa, osallistuvat kurssin markkinointiin eli hankkivat uusia pelaajia, demonstroivat peliä orientointitilaisuudessa, pitävät yhteyttä tiimeihin sähköpostitse vähintään 2-3 kertaa pelin aikana ja vastaavat peliä koskeviin teknisiin kysymyksiin. Tutorit voivat osallistua myös kurssin loppuarviointiin opettajatiimin kanssa. Tutorit on velvoitettu pitämään kirjaa töistään ja käyttämästään ajasta ja lopuksi he kirjoittavat raportin. Myös näin pyritään pääsemään mahdollisimman lähelle oikeita työelämän käytäntöjä.

\section{Strategy! ja vieraan kielen oppiminen}

Edustamani oppiaineen eli vieraan kielen kannalta peli tarjoaa oikeita kielenkäyttötilanteita. Teen parhaillaan tapaustutkimusta kahden tiimin käyttämistä vieraan kielen strategioista vuoden 1995 pelissä (Luukas 1997b). Tutkimukseni tuloksena on käynyt ilmi, että opiskelijoiden vieraan kielen strategioiden käyttö oli sujuvaa ja monipuolista eli pitkälle automatisoitunutta. Opiskelijoilla oli vain harvoin ongelmia vieraan kielen takia (kummallakin tutkitulla tiimillä vain kolme mainintaa lokikirjassa vieraan kielen aiheuttamista ongelmista ja ratkaisuista 12 pelikierroksen aikana). Strategioina käytettiin sanakirjan käyttöä, päättelyä asiayhteydestä tai kysyttiin muilta tiimin jäseniltä.

Todellisuudessa vieraan kielen ongelmia oli enemmän, kuten nauhoitettujen vieras- ja äidinkielisten neuvottelujen kielellinen analyysi osoitti. Mutta opiskelijoiden hyvästä kielitaidosta johtuen ongelmat ratkaistiin yleensä sujuvasti. Kohdekielen ilmaisun puuttuessa pelaajat turvautuivat usein kiertoilmaisuihin, äidinkielen tai muiden kielten ilmaisuihin sekä toistensa ja muiden henkilöiden apuun. Erityisesti toinen tutkituista tiimeistä kehitti kommunikaatiostrategiana pelin kuluessa oman 'fakkikielen', jota he käyttivät päätöksentekokeskusteluissa. Oma pelikieli loi ilmeisesti yhteenkuuluvuuden tunteen. Pelaajien käyttämässä kielessä voikin nähdä piirteitä käsitteestä 'antilanguage' (Halliday 1984), joka tarkoittaa suljetun piirin käyttämää kieltä.

Toinen vieraan kielen oppimiseen liittyvä seikka on ollut ulkomaisten partnereiden kulttuuritaustan huomioonottaminen sähköpostiviesteissä. Suomalaiset viestivät usein suoremmin kuin muissa kulttuureissa on tapana ja tämä on saattanut joskus aiheuttaa ongelmia. Yleensä suomalaiset opiskelijat ovat selviytyneet hyvin kielellisesti sähköpostiviesteistä. Voidaan tode- 
ta, että pelin pelaamisessa vieras kieli ei ole ollut ongelma. Ulkomaiset partnerit ovat olleet motivoiva tekijä, kun yhteistyö tiimin suomalaisten ja ulkomaisten jäsenten välillä on saatu toimimaan hyvin. Yhteistyön vaikeutuessa aikaeroista, teknisistä ongelmista tai kulttuurieroista johtuen on syntynyt myös turhautumista ja ongelmatilanteita. Sosiaaliset ja kulttuurienvälisen kanssakäymisen ongelmatilanteet ovat kuitenkin olleet hyödyllisiä. Kielenopettajana olen pyrkinyt toimimaan välittäjänä näissä tilanteissa niin, että lopputulos olisi aina "winwin“-tilanne. Etäkumppanit ovat olleet tärkeä pelin todellisuusulottuvuus.

\section{Loppupäätelmä}

Strategy! on osoittautunut mielenkiintoiseksi integroidun oppimisen kehittämisprosessiksi. Jokainen pelikierros on ollut ainutkertainen, sillä siihen osallistuvat pelaajat ovat tuoneet mukanaan lukuisia muuttuvia ja arvaamattomia tekijöitä. Uusia ongelmia on tullut koko ajan ja ne on pitänyt ratkaista nopeasti. Yksittäinen opettaja ei olisi niistä selvinnyt, mutta opettajatiiminä olemme onnistuneet. Opettajien hyvä yhteishenki ja sisäinen motivoituminen onkin edellytys tämäntyyppisen projektin onnistumiselle. Tutorien apu on myös ollut merkittävä. Tiimityöskentely on edellyttänyt uutta opettajan roolia: kukaan ei ole ollut yksin asiantuntija, mutta kaikki yhdessä, tutorit mukaanlukien, ovat muodostaneet toimivan kokonaisuuden, joka on ratkonut esiintulleita ongelmia yhteistoiminnallisesti ja asiantuntijuuteensa perustuen sitä mukaa, kun niitä on esiintynyt. Näin opettajista on tullut myös oppijoita.

\section{Iintest}

AITTO-OJA, A., JÄÄTTELÄ, R., KARJALAINEN, J., POHJALAINEN, S., ja SALONEN, L. (1993). Aloba! Säbköpostiprojekti. Seminaarityö. Helsinki: Suomen Liikemiesten Kauppaopiston opettajankoulutusosasto.

ANTTILA, I., KOIVISTO, E. ja STRÖMMER, R. (1995). Ammattikorkeakoulussa valmistaudutaan opetukseen vieraalla kielellä, Opettaja 37/95, 37-38.

BAILEY, E. K. ja COTLAR, M. 1994. Teaching via the Internet. Communication Education, 43, April 1994,184193
HALLIDAY, M. A. K. (1984). Language as social semiotic: the social interpretation of language and meaning. London: Edward Arnold.

HALONEN, E., KAHRI, I., PIETIKÄINEN, P., RAHIKAINEN, M., RÖNKÄ, K., ja SKÅTAR, K. (1994). STRATEGY!. Seminaarityö. Helsinki: Suomen Liikemiesten Kauppaopiston opettajankoulutusosasto.

Helia Opinto-opas 1997-1998. Helsinki: Helsingin liiketalouden ammattikorkeakoulu - Helia.

KAUPPI, A. (1995). Monimutkaiset yritysympäristöt avoimina oppimisympäristöinä. Helsinki: Opetushallitus.

LAVE, J. ja WENGER, E. (1995). Situated learning. Legitimate peripheral participation. Cambridge: Cambridge University Press.

LUUKAS, A. (1995). 'Report on approaches and methods for developing autonomy in advanced adult language learners of Business English' teoksessa Stenberg, K. (toim.). Report on Workshop 6B. "Learning to learn" languages in vocationally oriented education. Strasbourg: Council for Cultural Co-operation, 169-182.

LUUKAS, A. (1996). 'Euroopan neuvoston ammatillisen kielenopetuksen projekti' teoksessa von Essen, H., Luukas, A., Mustonen E. ja Niemelä, A-M 1996. Näkokulmia ammatilliseen kielenopetukseen, Helsinki: Opetushallitus, 7-22.

LUUKAS, A. (1997a). 'Empowering the student. Autonomous learning in Business English. A case study on the use of an integrated business simulation for foreign language learning' teoksessa Egloff, G. ja Fitzpatrick, A. (toim.) 1997. Languages for work and life: the Council of Europe and vocationally oriented language learning. Strasbourg: Council of Europe, 190-203.

LUUKAS, A. (1997b). "Let the games begin!" Second language strategies in a business game. Tekeillä oleva lisensiaattitutkimus. Englantilainen filologia, Jyväskylän yliopisto.

MARSH, D., OKSMAN-RINKINEN, P. ja TAKALA, S (toim.) (1996). Mainstream bilingual education in the Finnish vocational sector. Helsinki: Opetushallitus.

MARSH, D. (1996). Bilingual education, Tempus 8, 6-7.

PORTER, M. E. (1985). Competitive advantage: creating and sustaining superior performance. New York: Free Press.

PRIESMEYER, H. R. (1992). STRATEGY! A Business Unit Simulation. Administrator's Manual. Cincinnati, Ohio: South-Western Publishing

RAUSTE-von WRIGHT, M. ja von WRIGHT, J. (1994). Oppiminen ja koulutus. Juva: Werner Söderström.

RUOHOMÄKI, V. ja VARTIAINEN, M. (toim.). Simula tiopelit oppivan organisaation koulutusvälineinä. Raportti 140. Espoo: Helsingin yliopisto, Teknillinen korkeakoulu.

SAIKKU, S. ja RINNE K. (1993). Pelin vahvat puolet. Raportti - Strategy! Business Game. Helsinki: Helsingin liiketalouden va. ammattikorkeakoulu, 18.5. 1993.

White Paper on education and training. Teaching and learning - Towards the learning society 1995. Brussels: European Commission.

Lisätietoja: anneli.luukas@helia.fi 